\title{
ВИКОРИСТАННЯ АБСТРАКТНОГО ТА КАЗУЇСТИЧНОГО ПРИЙОМІВ ПРИ КОНСТРУЮВАННІ КРИМІНАЛЬНИХ ПРАВОПОРУШЕНЬ У СФЕРІ СВОБОДИ СЛОВА ТА ЖУРНАЛІСТСЬКОї ДІЯЛЬНОСТІ
}

\author{
ПАХНІН Микола Леонідович - кандидат наук 3 державного управління, \\ доцент кафедри кримінального права та кримінології факультету № 6 \\ Харківського національного університету внутрішніх справ \\ DOI 10.32782/EP.2021.4.13
}

В статъе рассматриваются вопросъи конструирования диспозиций норм об уголовнъих правонарушениях в сббере свободъ слова и журналистской деятельности, исследуются особенности применения казуистического приема законодательной техники, рассматриваются тенденции в регламентации составов правонарушений против законной профессиональной деятельности журналистов.

Ключевъе слова: норма права, законодательная техника, приемь, казуистический, абстрактнъий, преступление, свобода слова, журналист.

\section{Вступ}

Стаття 34 Конституції України гарантує кожному громадянину право на свободу думки і слова, на вільне вираження своїх поглядів і переконань, що включає право вільно збирати, зберігати, використовувати і поширювати інформацію усно, письмово або в інший спосіб - на свій вибір. Для захисту зазначеного права кримінальним законодавством запроваджено відповідальність за перешкоджання законній професійній діяльності журналістів (ст. ст. 171, 3451, 347-1, 348-1, 349-1 КК України). Поява у кримінальному законодавстві не тільки нових статей, пов'язаних з посяганням на свободу слова та журналістську діяльність, але й зміна дійсних суттєво ускладнило роботу правоохоронних органів з цього напрямку. Останні тенденції сучасного нормотворення не лише обтяжили розуміння кримінально- правових норм, але й практично унеможливили їх застосування в окремих випадках.

Проблемам, пов'язаним із розвитком i функціонуванням ЗМІ в сучасному суспільстві, присвячено низку фундаментальних і прикладних робіт, велику кількість наукових статей з юридичних, політичних, соціологічних наук та державного управління. Теорію масової комунікації та іiї засобів у загальному аспекті розробляли такі дослідники, як: Т. Адорно, Р. Барт, 3. Бауман, Д. Белл, Дж. Бенігер, К. Бєляков, В. Брижко, П. Бурдьє, Н. Вінер, Ю. Габермас, М. Горкгаймер, Б. Гунтер, Т. Ван Дейк, ж. Дельоз, Ж. Дерріда, Дж. Кері, О. Кузнецова, П. Аазарсфельд, Г. Аасвелл, Т. Маєр, Д. Макквейл, Т. Петерсон, Н. Петрова, І. Погорєлова, Т. Приступенко, Т. Роззак, Ф. Сиберт, В. Шрамм, В. Якубенко. Проблематикою кримінально-правового захисту діяльності засобів масової інформації займалися П. П. Андрушко, А. П. Бабій, П. С. Берзін, Я. С. Безпала, Р. В. Вереша, Ю. В. Городецький, I. О. Зінченко, В. М. Кудрявцев, С. Я. Аихова, Г. В. Аазутіна, А. І. Марущак, М. І. Мельник, О. В. Красильнікова, Н. В. Кушакова, В. I. Павликівський, А. В. Тарасенко, В. I. Тютюгін та ін.

Мета

Виявлення сучасних тенденцій у нормотворенні з питань кримінальної відповідальності за перешкоджання професійній 
діяльності журналістів та розроблення відповідних пропозицій із застосування чинного кримінального законодавства.

\section{Завдання}

Здійснити правовий аналіз на предмет доцільності використання казуїстичного способу законодавчої техніки при конструюванні кримінально-правових норм у сфері захисту свободи слова та професійної діяльності журналістів.

\section{Основний текст}

Ситуація із забезпеченням свободи слова та професійної діяльності журналістів в Україні залишається доволі складною. Учасники парламентських слухань «Безпека діяльності журналістів в Україні: стан, проблеми і шляхи їх вирішення», що відбулися 6 листопада 2019 року, розглянувши стан забезпечення безпеки діяльності журналістів в Україні визначили основні загрози професійній діяльності журналістів в Україні, якими, на їх думку, залишаються перешкоджання професійній діяльності, погрози та інші випадки фізичної агресії. За твердженням учасників зібрання, за перші дев'ять місяців 2019 року експертами зафіксовано 88 випадків фізичної агресії стосовно журналістів. Вперше за останні три роки в Україні було скоєно вбивство громадянського журналіста Вадима Комарова. Залишаються нерозкритими резонансні вбивства журналістів, зокрема Павла Шеремета. Не встановлені замовники вбивств Георгія Гонгадзе, В'ячеслава Веремія, Олеся Бузини та інших журналістів [1].

Як бачимо, ситуація, що склалася у цій сфері, викликає занепокоєння не тільки в громадських колах, але й на рівні законодавця. Для вирішення зазначених проблем депутати Верховної Ради тільки за останні декілька років подали близько десяти законопроєктів щодо посилення державно-правових гарантій у сфері забезпечення професійної діяльності журналістів. Два з них вже отримали статус закону, інші знаходяться на різних стадіях розгляду.

Зокрема, поданий народним депутатом В. В. Карпунцовим законопроєкт № 0924 рекомендував Верховній Раді України вне- сти до Кримінального кодексу України зміни щодо встановлення низки спеціальних складів злочинів:

- погрозу або насильство щодо журналіста, у тому числі, за здійснення такої погрози або насильства працівником правоохоронного органу, іншою службовою особою;

- умисне знищення або пошкодження майна журналіста;

- посягання на життя журналіста;

- захоплення журналіста як заручника.

Вказаний закопроєкт у подальшому став основою Закону України «Про внесення змін до деяких законодавчих актів України щодо посилення гарантій законної професійної діяльності журналістів» і був прийнятий 14 травня 2015 р. [2]. Таким чином, у розділі XV Особливої частини КК України з'явилась низка спеціальних норм про відповідальність за злочини проти журналістів:

- стаття 345-1 «Погроза або насильство щодо журналіста»;

- стаття 347-1 «Умисне знищення або пошкодження майна журналіста»;

- стаття 348-1 «Посягання на життя журналіста»;

- стаття 349-1 «Захоплення журналіста як заручника»;

Критиці журналістів за свою незначну ефективність піддавалася і основна норма про відповідальність за перешкоджання професійній діяльності журналістів (ст. 171 КК України). На складнощі правозастосування норми, передбаченої ст. 171 КК України, неодноразово звертали увагу в юридичній літературі, слідчі-практики та представники засобів масової інформації. У значній частині вони були пов'язані з проблемою визначення та неоднозначністю тлумачення таких понять, як «журналіст», «професійна діяльність», «перешкоджання законній професійній діяльності», «переслідування за виконання професійних обов'язків». У зв'язку 3 цим, народні депутати Верховної Ради, частина 3 яких 6 професійними журналістами, подали законопроєкт № 1630, спрямований на удосконалення законодавчої бази та усунення недоліків законодавчого регулювання питань, пов'язаних із чинним 


\section{Кримінальне право, кримінальний процес та криміналістика}

правовим механізмом забезпечення захисту професійної діяльності журналістів.

Зважаючи на численні недоліки та зауваження, які виникли до законопроєкту під час розгляду у ВР при першому читанні, цей законопроєкт, підготовлений до другого читання, суттєво змінився як за формою, так і за змістом [3]. Врешті, стаття 171 КК України отримала три частини, в одній 3 яких (ч. 1) законодавець спробував за допомогою казуїстичного прийому максимально доступно розкрити зміст перешкоджання законній професійній діяльності журналістів, зокрема незаконне вилучення зібраних, опрацьованих, підготовлених журналістом матеріалів і технічних засобів, якими він користується у зв'язку із своєю професійною діяльністю, незаконна відмова у доступі журналіста до інформації, незаконна заборона висвітлення окремих тем, показу окремих осіб, критики суб'єкта владних повноважень, а так само будь-яке інше умисне перешкоджання здійсненню журналістом законної професійної діяльності.

Можна сказати, що в правоохоронних органах не тільки залишились питання до попередньої редакції статті, а й виникло безліч нових, зокрема тих, що стосуються тлумачення терміна «перешкоджання», відмінностей між перешкоджанням і впливом, наявності лише двох кваліфікуючих обставин, які належать тільки до ч. 2 ст. 171 КК України у запропонованій редакції та багато інших [4, с. 78]. На жаль, незважаючи на те, що законопроєкт № 1630 зазнав суттєвих змін, а нова редакція, яка суттєво відрізняється від попередньої, була позбавлена широкого обговорення та наукового аналізу, 4.02.2016 р. Верховна Рада прийняла його в цілому, і 3.03.2016 р. Закон України «Про внесення змін до Кримінального кодексу України щодо удосконалення захисту професійної діяльності журналістів» набрав чинності [5].

Вітчизняне кримінальне законодавство у своїй більшості завжди було традиційно заощадливим у частині використання нормативного матеріалу. Однак в останні роки Особлива частина кримінального закону стала насичуватися казуїстичними нормативними приписами. Надлишкова казуїс- тика присутня не тільки у статтях про порушення свободи слова, алей достатньою мірою в інших розділах КК України (ст. 152, 153, 158-1, 159-1 КК України та ін.).

Здавалося б, слід підтримати прагнення законодавця передбачити максимально повний (на його думку) перелік видів можливої злочинної поведінки, описати можливі фактичні обставини злочину шляхом докладної і детальної вказівки на конкретні, індивідуальні ознаки. Це, на перший погляд. повинно максимально захистити об’єкт кримінально-правової охорони від нормативних прогалин, урізати широту судового розсуду і підвищити ефективність правоохоронної діяльності. Однак на практиці відбувається парадоксальна ситуація: чим складніше i багатослівніше описана диспозиція конкретної норми, тим рідше ця норма застосовується, чим більш казуїстичними стають окремі кримінально-правові норми, тим менше злочинців притягується до кримінальної відповідальності [6, с. 34]. Для підтвердження такого висновку скористаємося судової статистикою за кількістю зареєстрованих правопорушень та засуджених за перешкоджання законній журналістській діяльності. За даними Генеральної прокуратури України, з січня по вересень 2019 року правоохоронці зареєстрували 187 кримінальних проваджень щодо злочинів, скоєних стосовно працівників 3MI, 3 них 136 кримінальних проваджень зареєстровано за статтею 171 «Перешкоджання законній професійній діяльності журналістів» Кримінального кодексу України. Водночас із січня по вересень 2019 року правоохоронці розслідували та передали до суду лише 12 кримінальних проваджень щодо злочинів, скоєних стосовно журналістів (у 2018 році 22 справи, у 2017 році - 23 справи). Як бачимо, зміни в редакцію статті 171 КК України від 2016 року не допомогли практикам у реалізації положень закону.

Слід погодитися, що в такій ситуації зміни в чинне законодавство є назрілими та необхідними. Як було зазначено вище, спроби «модернізації»ст. 171 КК України робилися неодноразово, у тому числі депутатами професійними журналістами. У попередній редакції ч. 1 ст. 171 КК України мала досить 
лаконічний вигляд, передбачаючи відповідальність за «умисне перешкоджання законній професійній діяльності журналістів». На недосконалість такого формулювання неодноразово зверталася увага з боку представників правоохоронних органів [7], у зв'язку з чим було запропоновано декілька законопроєктів 3 реформування сфери кримінальноправового забезпечення свободи слова та діяльності журналістів, про що зазначалося вище. У своїх бажаннях покращити формулювання диспозиції статті 171 КК України законодавець пішов шляхом конкретизації окремих видів перешкоджання законній професійній діяльності журналістів, виділивши як самостійні форми такі дії: 1) незаконне вилучення зібраних, опрацьованих, підготовлених журналістом матеріалів і технічних засобів, якими він користується у зв'язку зі своєю професійною діяльністю; 2) незаконна відмова у доступі журналіста до інформації; 3) незаконна заборона висвітлення окремих тем, показу окремих осіб, критики суб'єкта владних повноважень, а також 4) будь-яке інше умисне перешкоджання здійсненню журналістом законної професійної діяльності. Таким чином, на думку ініціаторів законопроєкту, вказівка на конкретні види злочинного перешкоджання діяльності журналістів полегшить роботу правоохоронних органів і надасть останнім можливість прийняття безпомилкових рішень у частині кваліфікації посягань на журналістів.

На жаль, казуїстичний підхід у кримінальному правотворенні, а також поява нових норм про посягання на права журналістів не полегшили, а лише ускладнили судову практику, що і підтверджують вищезазначені статистичні дані про кількість направлених до суду кримінальних проваджень 3 перешкоджання законній професійній діяльності журналістів. «Надмірні подробиці у тексті закону ускладнюють користування ним і з точки зору технічної роблять закон незадовільним», - не без підстав зазначав М. Д. Шаргородський [8, .с. 60].

Абстрактний прийом опису притаманний досконалішіому ступеню розвитку законодавчої техніки. У той же час, використання казуїстичного способу допускається для деталізації кримінальної поведінки та конкретизації суспільно небезпечного діяння або його наслідків. Так, у статті 236 КК України абстрактний прийом опису суспільно небезпечних наслідків доповнюється конкретними прикладами, що дозволяє більш точно окреслити характер та обсяг шкоди, спричиненої порушенням правил екологічної безпеки. 3 іншого боку, різноманітність злочинних дій, а також прийомів та методів вказують на важливість саме абстрактного (узагальненого) способу опису протиправної поведінки. Так, у ч1. ст. 263 КК України з поданого переліку незаконних дій з вогнепальною зброєю наявні і передача і збут, при цьому в ч. 2 ст. 263 КК України стосовно холодної зброї лише збут. Намагання законодавця описати за допомогою конкретних випадків той чи інший вид злочинної поведінки буде призводити до необхідності подальшого внесення відповідних змін у чинне законодавство. Так, протидія законній господарській діяльності (ст. 206 КК України) у вигляді захоплення цілісного майнового комплексу, його частини, будівель, споруд, земельної ділянки, об'єктів будівництва, інших об'єктів та незаконне припинення або обмеження діяльності на цих об'єктах та обмеження доступу до них не може охопити всіх різновидів рейдерського захоплення, що в майбутньому потребує від законодавця доповнення статті новими злочинними способами. Аналогічна ситуація спостерігається і стосовно виборчих правопорушень (ст.ст. 158-1, 159-1 КК України), останні зміни в яких пов'язані з намаганням законодавця перерахувати всі можливі способи фальсифікацій або ж порушень голосування. Так, ч. 2 ст. 159-1 КК України встановлює відповідальність за порушення порядку фінансування політичної партї̈, передвиборної агітації чи агітації референдуму, зокрема: умисне здійснення внеску на підтримку політичної партії; умисне здійснення внеску на користь політичної партії; умисне надання фінансової (матеріальної) підтримки для здійснення передвиборної агітації чи агітації референдуму. Логічнішим у цьому випадку виглядає використання усталеного законодавчого прийому: «незаконне 


\section{Кримінальне право, кримінальний процес та криміналістика}

фінансування політичної партії у великих розмірах» [9, с. 199].

Таким чином, доповнення ст. 171 КК України окремими видами перешкоджання (вилучення матеріалів, відмова у доступі до інформації, заборона публікації) навряд чи може вплинути на якість використання кримінально-правової норми. У той же час поява спеціальних норм про відповідальність за шкоду життю, здоров’ю, волі та власності журналіста суттєво ускладнили розуміння їх співвідношення з загальною нормою та питання кваліфікації протиправних посягань на свободу журналістської діяльності.

Зазначаємо, що в цілому поява такої кількості статей не тільки не спрощує, а навпаки ускладнюе кримінально-правовий захист журналістських свобод і призводить до суддівських помилок або необгрунтованого виправдання винних у порушеннях свободи слова.Вказівка у ч. 1 ст. 171 КК України на окремі форми перешкоджання професійній діяльності журналістів не вирішує більшості проблем правозастосовної практики. Якщо вилучення зібраних, опрацьованих, підготовлених журналістом матеріалів і технічних засобів, якими журналіст користується у зв'язку зі своєю професійною діяльністю є лише однією з форм перешкоджання професійній діяльності, у такому випадку залишається питання, чому відсутня вказівка на інші, більш небезпечні форми перешкоджання, зокрема побиття журналістів, залякування, цензура. I взагалі, чи відносяться такі форми до перешкоджання або потребують окремої кваліфікації. Судова практика, не маючи грунтовних теоретичних рішень 3 цього питання, не відрізняється однаковим застосування закону. Так, дії особи, пов'язані з перешкоджанням законній професійній діяльності журналіста та нанесенням легких тілесних ушкоджень, були кваліфіковані Саксаганським районним судом м. Кривого Рогу Дніпропетровської області за ч.1 ст. 171, ч.1 ст. 125 КК України [10].У схожій ситуації Дніпровський районний суд м. Києва перешкоджання журналістській діяльності та нанесення тілесних ушкоджень журналісту кваліфікував лише за ч. 2 ст. 345-1 КК України [11]. Спостерігаються й інші підходи до вирішення вказаної про- блематики, наприклад кваліфікація за сукупністю статей 171 та 345 КК України.

\section{Висновки}

Розглядаючи співвідношення абстрактності і казуїстичності в описі диспозиційкримінально-правових норм, у тому числі за перешкоджання законній професійній діяльності журналістів можна виділити наступні тенденції.

Так, у багатьох випадках законодавець без врахування особливостей та традицій національного законодавства намагається перенести (копіювати) положення міжнародних актів на вітчизняне нормативне поле. У цілому таке рішення призводить не тільки до появи непритаманній національному законодавству термінології, але й викликає суттєві складнощі у правозастосовній практиці.

В інших випадках, законодавець, полегшуючи собі завдання і не обтяжуючи себе спробами уніфікувати термінологію, піти від зайвої казуїстичності, просто намагається перелічити найбільш типові приклади кримінальної поведінки та «обрамляє» їі вказівкою «а також інше суспільно небезпечне діяння» або наявністю злочинних наслідків, доводячи тим самим зміст суспільної небезпеки до рівня, необхідного для криміналізації.

Очевидно, що реформування норм про перешкоджання, збільшення ї казуїстичності, а також виділення спеціальних видів посягань на журналістів не відповідає вимогам законодавчої техніки і потребам правозастосовної практики. Основним завданням законодавця в таких умовах має стати вироблення простих, ясних, логічних невеликих за обсягом диспозицій, що закріплюють ознаки складів правопорушень у сфері свободи слова та журналістської діяльності.

\section{Мiтература}

1. Постанова Верховної Ради України № 456-IX від 14 січня 2020 року «Про Рекомендації парламентських слухань на тему: «Безпека діяльності журналістів в Україні: стан, проблеми і шляхи їх вирішення»». URL: https://zakon.rada.gov.ua/ 


\section{АНОТАЦІЯ}

У статті розглядаються питання конструювання диспозищій норм про кримінальні правопорушення у сбері свободи слова та журналістської діяльності, досліджуються особливості застосування казуїстичного прийому законодавчої техніки, розглядаються тенденцї у регламентаціӥ складів правопорушень проти законной пробесійной діяльності журналістів.

Ключові слова:норма права, законодавча техніка, прийоми, казуїстичний, абстрактний, злочин, свобода слова, журналіст.

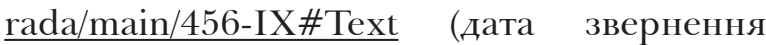
1.11.2021).

2. Закон України «Про внесення змін до деяких законодавчих актів України щодо посилення гарантій законної професійної діяльності журналістів» від 14.05.2015 р. // Відомості Верховної Ради (ВВР). 2015. № 29. Cт. 264.

3. Проект Закону «Про внесення змін до Кримінального кодексу України (щодо удосконалення захисту професійної діяльності журналістів)» від 25.12.2014 р. № 1630. URL: $\quad$ http://w1.c1.rada.gov.ua/pls/zweb2/ webproc4_1?pf3511=53168 (дата звернення $1.11 .2021)$.

4. Павликівський В. І. Кримінальноправове забезпечення свободи слова та професійної діяльності журналістів в Україні. Харків: Панов, 2016. 488 с.

5. Закон України «Про внесення змін до Кримінального кодексу України щодо удосконалення захисту професійної діяльності журналістів» від 04.02.2016 № 993-VIII. URL:http://zakon3.rada.gov.ua/laws/show/99319/paran2\#n2 (дата звернення 1.11.2021).

6. Соловьев О. Г. Использование абстрактного и казуистического приемов в конструировании составов экономических преступлений (гл. 22 УК РФ). Актуальные вопросы борьбы с преступлениями. 2014.№ 1. C. $32-34$.

7.Стенограма засідання Міжвідомчої робочої групи з аналізу стану додержання законодавства про свободу слова та захист прав журналістів. URL:http://www.president. gov.ua/news/23329.html (дата звернення $1.11 .2021)$.

\section{SUMMARY}

The article considers the issues of constructing dispositions of norms on criminal offenses in the field of freedom of speech and journalistic activity, examines the peculiarities of the application of casuistic methods of legislative technique, trends in the regulation of offenses against lawful professional activity of journalists.

The analysis of casuistry and abstractness in the description of the dispositions of criminal law, including those related to the obstruction of the lawful professional activity of journalists, revealed the following trends.

In many cases, without taking into account the peculiarities and traditions of national legislation, the legislator tries to transfer (copy) the provisions of international acts to the domestic regulatory field.In other cases, the legislator simply tries to list the most typical examples of criminal behavior and "frames" it with instructions "as well as other socially dangerous acts" or the presence of criminal consequences, thus bringing the content of public danger to the level necessary for criminalization.

In general, it is concluded that it is necessary to revise the legislation on liability for obstructing the legitimate professional activities of journalists and to develop simple, clear, logical small dispositions that establish the characteristics of offenses in the field of freedom of speech and journalism.

Key words: rule of law, legislative technique, methods, casuistic, abstract, crime, freedom of speech, journalist.

8. Шаргородский М. Д. Техника и терминология уголовного закона. Советское государство и право. 1948. № 1. С. 58-65.

9. Иванчин А. В. Абстрактный и казуистический приемы в уголовном правотворчестве. Юридическая техника. 2010. № 4.С. 195-199.

10. Вирок Саксаганського районного суду м. Кривого Рогу Дніпропетровської області від 29.03.2019. Справа№ 214/4970/18. URL:https://reyestr.court. gov.ua/Review/80823666 (дата звернення 1.11.2021).

11. Вирок Дніпровського районного суду м. Києва від 15.08.2018 р. Справа № 755/19002/17. URL:https://reyestr.court. gov.ua/Review/76753390 (дата звернення 1.11.2021). 